\title{
The Function of Religious Language in the Media: A Comparative Analysis of the Japanese, German and American Newspaper Coverage about the 2011 Great East Japan Earthquake and Tsunami
}

\author{
Yukiko Sato $^{\#}$, Ikumi Waragai ${ }^{\#}$ \\ ${ }^{\#}$ Graduate School of Media and Governance, Keio University, Endo 5322, Fujisawa, 252-0882, Japan \\ E-mail:yukisato@sfc.keio.ac.jp,ikumi@sfc.keio.ac.jp
}

\begin{abstract}
When an incident or event in a certain region will be reported by the mass media in a different language, the choice of expressions, the perspective and aim of their message will differ. This study analyzes the news coverage of events related to the 2011 Great East Japan Earthquake and Tsunami in German, American and Japanese newspapers. It will aim to uncover expressional differences in the coverage on a similar topic reported in different languages. This research especially focuses on the use of religious language in the coverage, which in this paper refers to religious metaphors and symbols originating from a Christian context. Previous research shows that the use of religious language in the media, affects consumers mentally and emotionally. Based on that theory, this study compares how religious language is used in the coverage and tries to clarify the functions of religious expressions through a critical discourse analysis. The results show that religious language appears continuously in German and American news reports related to the disaster. Religious language is mostly used symbolically as well as metaphorically in order to illustrate the destruction caused by the earthquake, tsunami and nuclear disaster, while at the same time conveying emotions such as the fear of the victims. It is also used to describe the difficulties, suffering and hope of the people in the disaster-hit area. Moreover religious language provokes emotions in the readers and makes it easier for them to understand the situation in Japan as well as the feelings of the disaster refugees. A difference between the German and American news coverage was seen in the description of the situation at the nuclear power plant and the state of the victims in Fukushima and the Tohoku region. In Germany, religious language can change the viewpoint of and provoke emotions in the readers. It is also employed to emphasize domestic social and political problems related to German energy policy.
\end{abstract}

Keywords—Language and Media; German and American News Coverage; Religious Language; 3.11 News Reports

\section{INTRODUCTION}

This study concentrates on the choice of expressions used in the media coverage and will attempt to analyze several aspects of this phenomenon in the area of cross cultural news coverage, where the basic topic of the news item will be reported in several different languages.

The scale of the diverse processes of sending out information is expanding and becoming more complicated every day. Especially, the expansion of the Internet made the existence of a process of daily information searching and collecting possible. Information, as we see it today, refers not only to the information sent from our local community, but also to the information from the Internet. Focusing on news coverage, even though it is possible to access any kind of information in the world through the Internet, the chance to receive information directly from the local region, where specific events or incidents occurred, is rather limited. As Ogiwara and other researchers highlight, the Japanese media system is dependent on American or British news agencies like AP (USA) or Reuters (GB) in order to cover events throughout the world [1]. This means that the news we receive from around the world could be limited by AngloSaxon perspective and expressions. Therefore, it is possible that the information we obtain about the world is strongly influenced by one language, limiting the content of information we receive about events throughout the world.

However, when an incident or event happens in a certain area and it will be received and covered in a different language, sending the news to another region, not only the semantic expressions used, but also the message will change. The choice of expression used in the media reports will differ, as well as the perspective, important points and the aim of their message. Then what kind of differences can be actually seen between the contents of the news coverage reported in different languages? What kind of difference can be found between the coverage and the reception of the coverage? The goal of this research is to uncover the differences between the news items concerning the same 
topic, as well as the expressions used in these news items and its perspective in several languages. For example this research will focus on how the foreign media would perceive and describe events happening in Japan in their language. To discover how events in Japan are reported in the news coverage of foreign news media and what kind of differences can be seen, this paper compares the German, American and Japanese news coverage reporting about the same theme to uncover the expressional differences evident in the news coverage.

When analyzing the news items, this research will especially focus on the use of religious language in the coverage. Gottwald and Schultze explain the use of religious language in the mass media, such as religious symbols, metaphors and other signs. They are normally encountered in the field of religion, which is a sharp contrast to the field of political and economic news coverage [2], [3]. Concerned with the process of adapting a news item into another language, Ishiguro explains that the Japanese media will ignore the use of religious expressions when reporting based on news items from Western countries [4]. She also argues that the recipients of the media coverage will not be able to understand the main message of the original source. This phenomenon is also mirrored by the sending and receiving process of Japanese news coverage, reported in foreign countries. Also, previous research shows that the use of religious language in the media, affect the consumers mentally and emotionally [5].

This research postulates that such expressions play a role in the news content, that they obtain a special language function, as a method for internal representation affecting the reader's emotional response to a news article. Especially focusing on the coverage in America and Europe, with different religious contexts but shared social values, the main goal of this research is to investigate, how they report information from Japan, what position it will be placed in, what kind of expressions will be used and how the context can change through the coverage.

In order to answer these questions, this research will investigate newspaper articles related to the theme of the Great East Japan Earthquake, Tsunami and Nuclear Catastrophe, which occurred in Japan on March 11th 2011 (3.11), and compare the text data from the Japanese, American and German articles, analyzing the content from a linguistic/semantic view point. The analyzed data will be recorded into a database, making it possible to count and to categorize the tendency of the functions of the religious language found in the news contents about the triple catastrophe in Japan.

After the Tohoku earthquake, tsunami and nuclear catastrophe in Japan 2011, information related to the 3.11 catastrophe has been broadly discussed in the field of media studies. Previous investigations concerning the news coverage about the disaster in Japan on March 11th have been published in many forms. The Japanese news coverage itself has been compiled and published by Japanese newspapers, e.g. in the form of a "Complete compilation of press photos about the Great East Japan Earthquake from 2011.3.11-4.11" by the Asahi Shimbun [6], or the "Compilation of Yomiuri Shimbun press photos on the Great
East Japan Earthquake", by the Yomiuri Shimbun [7] in 2011.

Regional newspapers and Japanese news agencies have published similar compilations of news articles, such as the "Complete compilation of the Great East Japan Earthquake: A report from the disaster area" published by the Kahokushimpou [8] or "The Great East Japan Earthquake special press photo compilation" by Kyodo News [9].

A critical examination of the newspaper coverage can be seen in Fackler or Uesugi's work. After the 3.11 disaster journalists and scholars have questioned the accuracy of the mass media, criticizing that the government has controlled and manipulated information relating to the catastrophe [10], [11].

Other researches have focused on how foreign media reported about the catastrophe, as well as how mass-media contents have affected the people and society. This can be seen in research papers from Yokouchi et. al (2012) [12] or Sakai (2015) [13] focusing on the content of the foreign newspaper coverage about the 3.11 disaster in Japan. Wolling and Arlt [14], as well as Koch [15], analyze and compare European and American news reports through a statistical framing analysis and investigate changes in the public opinion.

Furthermore, several researches have emphasized the effect of religious language in the media. Many have focused on religious terms as a tool for the expression of certain messages in media such as news reports, literature and popculture [16], [17]. As Orgad shows, religious representations, words and symbols in news reports have been appearing as early as 1755, after the Lisbon earthquake in Europe, in order to illustrate the disaster as well as to convey the suffering of the people [18].

Researches exploring the use of religious language, describe that it is mostly used as a method to deliver propaganda during times of war. For example, Miyata says that the biblical expressions, symbols and metaphors which appear in the stories in the bible, or other liturgical terms used in church services have the effect of conveying political thoughts of politicians [19]. Chomsky and Charteris-Black have also explained that the use of religious language in political discourse is a method to justify war. Other statements have also included the function of conveying the political opinion of the public, by using religious elements as a method of media control [20], [21].

Based on the theory, that religious language has often been used in the media to convey political ideas and legitimize political acts to the public, this research will focus on the news coverage related to the earthquake and tsunami in Japan 2011, considering the possible political effects of religious language in the media. This study will examine the meaning, as well as the function of such religious elements used in news reports on the recent catastrophe that occurred in Japan in 2011, and describe what kind of similarities and/or differences can be seen as compared to the functions mentioned in previous research. Through the analysis of articles related to the three disasters in Japan that occurred in 2011, this study will compare articles of German and American newspapers to the Japanese articles and analyze the data concerning the use of expressions. By comparing the two different languages (German and English) this study 
will serve as a comparative analysis to clarify the differences in perspective between Europe and America.

\section{MATERIAL AND METHOD}

This study conducts a critical discourse analysis (CDA). This approach aims to analyze social power (the ability of a social group or institution to control the actions and the worldviews of others) in spoken and written statements to point out that they are not natural and inevitable but socially constructed, also seeking to make their ideologies visible, focusing on the whole underlying meaning of the text [22]. As van Djik argues, given a specific context, certain meanings and forms of discourse have more influence on people's minds than others. Furthermore CDA also focuses on how discourse structures influence mental representations, using the term of "mind control" to describe one of the forms in which powerful groups control public discourse [23]. Studying discourse by comprehending language as a form of social practice, Titschner, Meyer, Wodak, and Vetter describe the analytical framework of CDA, which is based on Halliday's multifunctional linguistic theory, that every text has an "ideational" function through its representation of experiences and representation of the world [24]. This enables the interpretation of the functions of religious expressions in texts appearing in the newspaper coverage, which signifies the experience of journalists from a particular perspective. The critical discourse analysis conducts the following text analysis, which analyzes the content and form of a text on a linguistic level, which includes grammar, vocabulary and semantics. On the textual level this research adapts three approaches from discourse analysis in (mass) communication research [25], 1) newspaper content analysis [26], 2) analysis of religious languages in the secular context [27] and 3) quantitative text analysis of the articles. Texts must be analyzed from various levels. Surface properties, such as presentation, layout and graphical display, the analysis of syntactic structures, lexical style or rhetorical devices, as well as the examination of the underlying meanings, connotations or associations must be analyzed [23].

In order to analyze the surface properties of a newspaper article, this research refers to the content newspaper analysis method recording information about the text data (title, subtitle, main text), picture (picture, under-title), graphs, the name of the newspaper, the publication date, section, layout, the number of words and the size of the article, recording all into a database. For the semantic level of the analysis this research especially focuses on religious language. The use of the term "religious language" in this research adheres to the definition of Cruse, who defines religious language on two levels, which are 1) obviously biblical terms, such as god, heaven, belief, baptism and church, hereafter called primary religious words, and 2) a wide selection of words, with, at first glance, little relevance to biblical metaphors and symbols, such as apple, dust, blind and man, which can however be interpreted as biblical language, depending on their context. For this research, the status of an expression as belonging to the category of "religious language" will be determined by use of symbol lexicons, liturgical books and the Bible [28]-[30]. In addition, a qualitative text analysis will be conducted by using a text analysis tool in order to study the semantic level, by identifying frequent key words used in the article to clarify which religious element belongs to what kind of context in which kind of theme or story. All information will be stored in a database, making it possible to categorize, as well as analyze the frequency of the religious terms used in the news coverage. A comprehensive analysis from the steps 1) to 3) will be conducted in order to examine and categorize the various functions of religious elements in the coverage, related to the 2011 earthquake, tsunami and nuclear disaster, considering how the elements could change the context focusing on how they could be received by the readers based on the context they are used in (See Fig. 1).

In this study, newspaper articles from the following different types of quality daily national newspapers in each country will be analyzed, selected because of their difference of circulation and region in Germany, America and Japan. For Germany, The Süddeutsche Zeitung (SZ) and Frankfurter Allgemeine Zeitung (FAZ) will be analyzed [31]. The SZ is a center-left quality newspaper with its headquarter in Munich, Southern Germany. The newspaper is positioned as the most subscribed national newspaper with its reader base located mainly in southern Germany, which also implicates the possibility that it focuses on delivering information to its readers in the local area. FAZ is a centerright quality newspaper with the second largest circulation and the widest circulation abroad. Its readers are mainly made up of political and economic leaders and elites in Germany. The New York Times (NYT) and the Washington Post (WP) are selected to analyze the American news coverage [32], [33]. NYT is one of the most influential newspapers in America as well as worldwide, having the second largest circulation among the quality newspapers in the United States and a strong liberal slant. The WP was selected for the reason that its coverage concentrates especially on the politics of the United States adapting a moderate stance. For Japan, the Asahi Shimbun and Yomiuri Shimbun are included into the analysis. The Yomiuri Shimbun is described as a conservative newspaper, while the Asahi Shimbun shows a liberal oriented stance [34]. Starting with the year 2012, one year after the earthquake, the news coverage will be collected and analyzed. This research focuses on the newspaper coverage occurring after 2012, rather than starting in 2011 in order to investigate and differentiate how the incident is being reviewed, in the media coverage.

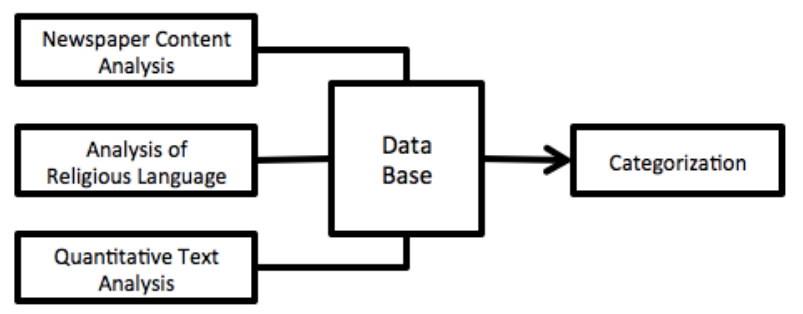

Fig. 1 Process of the text analysis 


\section{RESULTS AND DISCUSSION}

In this paper 610 articles published from March 2012 until December 2016 were collected and analyzed.

Fig. 2 shows the tendency of the amount of the articles of the national German newspapers and Fig. 3 shows the tendency of the published article in the American news coverage about the 3.11 related events in Japan, which were published from 2012 to 2016. Comparing the amount of the foreign coverage from Germany and America, it could be seen that the German national newspaper reported twice as more as the national American newspapers about the issues in Japan related to the catastrophe in Japan after 2011. The FAZ, which is known for its conservative position and the most distributed quality national German newspaper in the world, reported the most about the 3.11 catastrophe related Japanese news.

Considering the newspaper's character of FAZ, which is the most subscribed newspaper from German elites, it could be seen that the catastrophe in Japan is a continuous issue in the German politics and economy. In America the NYT had been focusing more on the critical 3.11 related problems in Japan.

Both newspapers in Germany and America have been reporting from its original resources (the articles are written by their own correspondents) or from news agencies belonging to their own country (dpa or AFP in Germany and AP or Reuters in America). Although the both graphs shows that the number of articles decreases throughout the year, but nevertheless the problems of the catastrophe in Japan continue to be reported in both countries, especially the number of articles increase in March every year.

In this investigation a total of 29 articles in German and English, that included religious expressions were taken into account, with a total of 38506 words, 2434 sentences and 37 pictures.

Religious terms, despite their small number, appear continuously throughout 2012 and 2016 in German and American articles. Religious terms continue to be used mostly in the FAZ, SZ and NYT in titles or texts of the article. In total 44 religious expressions including 2 pictures were found, 23 in German and 21 in English articles. On the other hand, Christian related religious terms were not found in the Japanese news coverage.

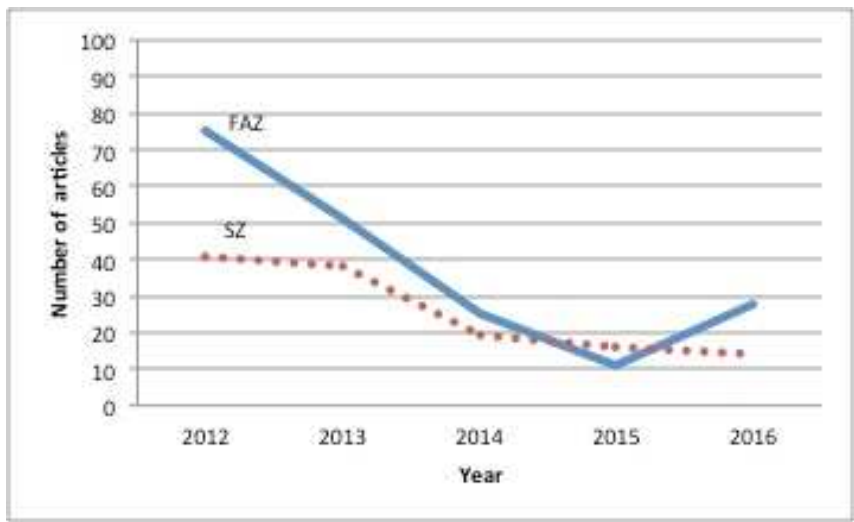

Fig. 2 Tendency of the amount of articles related to 3.11 events in Japan in German newspapers from 2012 to 2016

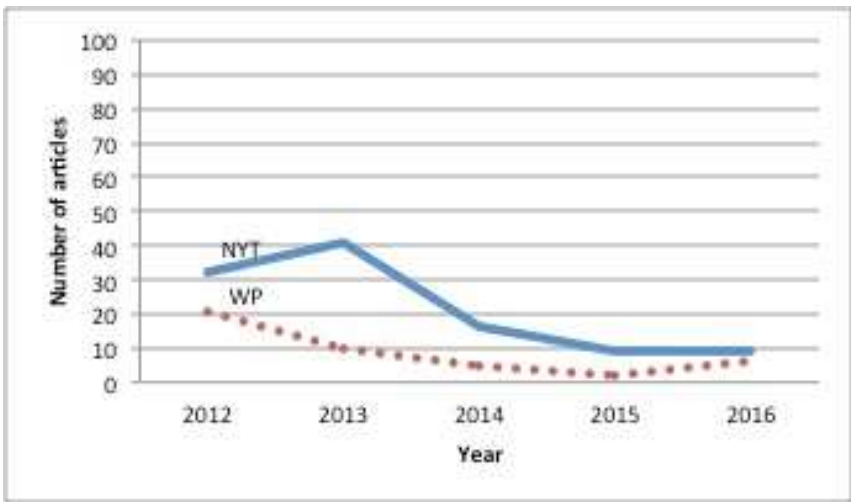

Fig. 3 Tendency of the amount of articles related to 3.11 events in Japan in American newspapers from 2012 to 2016

\section{A. Text Analysis of German News Coverage}

Fig. 4 shows the frequency of religious terms appearing in German national newspapers. By analysing the main frequently used words and religious terms in the German articles, the functions of the religious language employed here can be grouped into categories A to $\mathrm{M}$. The terms "Apokalypse" and "Menetekel" were used frequently in different articles.

"Apokalypse" (engl. Apocalypse; all translations by the author) which is used for a representation for disasters in the modern context originally comes from the description of the "End of the World" written in the Revelation of John (Offb.) of the New Testament [35], [36]. The term was used to symbolize the natural disaster and nuclear catastrophe in the German articles continuously from 2012 to 2016.

The word "Apokalypse" was found in articles in 2012 (Article SZ1), 2013 (FAZ1) and also 2016 (SZ2, SZ3). "Apokalypse" is used to describe the destruction of a city from the tsunami catastrophe in 2011 (Category A). This can be seen in FAZ1 and SZ1. FAZ1 was published on page 13 of the business column on March 9th 2013, titled "Neuanfang mit Hindernissen" (New start with difficulties) [37]. The main frequent key words are: "Kesenuma", "Tsunami" and "Stadt" (city). The article focuses on the heavily damaged city of Kesenuma, and the still struggling victims of the tsunami. The one page article was published with a photograph of a temporary restaurant street. The article unfolds based on a story from a fisher in Kesenuma on how the city is struggling with the spreading fear of radiation-contaminated fishes and not being able to revive its local fishing industry. The word "Apokalypse" was used in a quote from an interview, "Es waren Bilder der Apokalypse" (It was like scenes of the Apocalypse) as the fisher recalled the Tsunami catastrophe in 2011. At the end, another religious term "wiederauferstehen" was used, which refers to the resurrection of God or the soul, as the city mayor of Kesenuma ended the article with his resolution as "wiederauferstehen und überleben können wir nur mit dem Meer" (we can only survive and rise again together with the ocean). With the "Apokalypse" at the beginning and "wiederauferstehen" at the end, the combination refers to the Revelation of John. Expressing the tsunami disaster by using the term "Apokalypse" not only illustrates the damaged state of Kesenuma but also emotions such as fear and pain of the 
people who experienced the catastrophe. With both terms there is also a question attached to the context of the article, whether the city of Kesenuma and its citizens can recover in the future.

SZ1 was printed on page 2 of the "Thema des Tages" (Today's theme) column on March 10th 2012 [38]. The entire page consists of articles related to the catastrophe in Fukushima and featured the anniversary in Japan and the state of nuclear plants in emerging countries. With 623 words the article framing Japan was placed on the bottom of the page. Another article, featuring a nuclear plant in Korea, was placed in the center (one third of the page) with a photograph of the accident in Fukushima. Written in 911 words a headline from a quote of a Korean worker "Die deutsche Energiewende wird international mit Verwunderung aufgenommen" (The German Energiewende was taken with astonishment internationally) was inserted between the paragraphs with a bigger font size compared to the others. On the top of the entire page an introduction was written with 92 words titled "Fukushima - ein Jahr danach" (Fukushima - one year later). This short introduction, looking back at the catastrophe in 2011, linked the tsunami with the image of apocalypse by describing "Genauso apokalyptisch wie die Bilder vom Tsunami, der fast 20000 Todesopfer forderte, wirkten die Explosionen im Kernkraftwerk Fukushima" (The explosion in the nuclear power plant in Fukushima appear as apocalyptic as the images from the Tsunami, which caused 20000 victims to die). Looking at the layout of the page SZ1 was published on, the articles about Japan were not only included to illustrate the catastrophe. They also serve as a tie-in to articles on the domestic German debate of the "Energiewende" (energy transition).

As seen in SZ1, "Apokalypse" was also used to illustrate the state of the nuclear disaster and the situation after the catastrophe near the Fukushima Dai-ichi power plant station (Category B). This could be seen in SZ2 and SZ3. SZ2 was a one-page article printed on the page 3 politics column on May 20th 2016 [39]. The main key words were: "Naraha", "wieder" (again) and "Priester" (priest). Article SZ2 titled "Stunde eins" (Hour one) included a picture of a house in the contaminated area of Fukushima surrounded by garbage bags of contaminated soil on the top. The article focuses on a story about the slowly progressing task of decontamination in the area of the cities Iwaki and Naraha in Fukushima prefecture, which have been made accessible again. In the article, the term "Apokalypse" appears in the following quote: "Was man für den Beginn der Apokalypse halten möchte, in diesen Märztagen 2011, hatte auch den Priester Hayakawa vertrieben" (what could be considered as the beginning of the apocalypse in these days of March 2011, has also driven out the priest Hayakawa). From this sentence the image of the severe disaster from the nuclear accident could be received, as well as the continuous fear of the residents in the disaster zone, relating to the same fear from the apocalypse. In addition, the question about the possibility of the redemption of Fukushima is invoked. The same theme can be seen in SZ3, which was printed on the film column on March 10th 2016 [40]. The main key words are: "Kamera" (camera), "Fukushima", "Grüße" (greetings) and "Doris" (a female name). A movie called, "Grüße aus
Fukushima", directed by the German film director Doris Dorrie was introduced. The title "Schönheit der Apokalypse" (The beauty of the Apocalypse) shows that the image of the apocalypse would reflect the area of the nuclear disaster, which can affect the image of Fukushima to the readers provoking the hope of redemption.

"Menetekel" was also frequently used in the German newspapers. "Menetekel" refers to a bad omen, which originates from the message of impending doom sent by God in the Book of Daniel (Dan. 5). This term was used to describe the nuclear power plant in Fukushima as well as the Japanese society regarding the governments handling of the catastrophe from year 2013 to 2016. The religious term was used in articles from 2013 (FAZ2), 2015 (FAZ3) and 2016 (FAZ4).

"Menetekel" was used in order to describe the situation of the use of the Fukushima nuclear power plant in Japan (Category C). This can be seen in FAZ2, which appeared in the art section [41]. The main key words are: "Fukushima", "Schrein" (shrine), and "Architekt" (architect). FAZ2 with the title "Fukushima bleibt nur Totenwache" (Fukushima remains as a vigil), reports about an exhibition of a Japanese architect seeking to change the nuclear plants in Fukushima into Shinto shrines. A picture of the model was placed above the text described as "Ein Menetekel des Atomzeitalters: Der Architekt Katsuhiro Minamoto will die morschen Reaktoren von Fukushima mit 8 traditionellen Holzdächern zum Shinto-Schrein wandeln" (A Menetekel of the nuclear age: The architect Katsuhiro Miyamoto wants to change the decaying reactors from Fukushima with traditional tree roofs into Shinto shrines). The word "Menetekel" is a metaphorical word in the modern text as a term for a bad omen. But from a Christian point of view, it refers to an omen of death which is written in the Book of Daniel in the Old Testament (Dan. 5). Here, the readers could obtain a negative image of the nuclear reactors from "Menetekel", referring to death, which could also invoke fear of the atomic generators in the readers. Also the perception of the readers will change, from the context of a news report about Japanese reactors in Fukushima to a context of the bad omen of nuclear reactors in general.

"Menetekel" was also used to criticize the Japanese government by comparing the situation to the policy in Germany, which could be seen on FAZ3 and FAZ4 (Category D). FAZ3 was printed on the business column on May 20th 2015 [42]. The main key words are: "Regierung" (government), "Energie" (energy) and "Kernkraft" (nuclear power). FAZ3 was written with the title "Mit Kernkraft und Kohle" (With nuclear power and coal) criticizing the energy plan of the Japanese government since 2012, affecting the countries soaring energy price, whilst predicting that the consumption of coal will increase. The article criticized the government's plan as "Für Japans Anstrengungen zur Verringerung von Kohlendioxid und anderen sogenannten Treibhausgassen ist das ein Menetekel" (This is a Menetekel for Japans devotion to the reduction of carbon dioxide and other green house gases). "Menetekel" was used as a term to criticize the policy in Japan. Also the article compares this to the energy policy in Germany where energy prices are also surging. Through the use of "Menetekel", the text can 
provoke the consideration of the readers against their own energy plan that their own country is also facing a problem.

FAZ4 appeared on the business column on March 9th 2016 [43]. The main key words are: "Japan", "Wiederaufbau" (reconstruction) and "Deutschland" (Germany). FAZ4 was printed with the title "Japans Lehren nach dem Tsunami” (Japan's lesson after the Tsunami), reporting about the situation in the tsunami-stricken Fukushima area five years after the catastrophe. The article focuses on the pending reconstruction in the Tohoku area describing: "Der sich dahinschleppende Wiederaufbau ist so ein Menetekel dafür, dass Japan nichts mehr braucht, als eine Abkehr vom Zentralismus und eine drastische Dezentralisierung" (The delaying reconstruction is as such a Menetekel, that Japan needs nothing more than renunciation of centralism and a drastic de-centralization). This article compares the reconstruction of eastern Germany to the reconstruction in Japan, which could function in the same way as in the articles above, not only meant to criticize Japanese politics but also implicating a negative image and critical view of German domestic politics.

The religious term "Sündenbock" (scapegoat) was twice found in a context relating to the problems of the nuclear plant in Fukushima in 2013. "Sündenbock" refers to a person, who is accused on someone else's behalf [44]. The word has its origins in the Old Testament (3.Mose 16:21). It was used to express that Tepco was a scapegoat for the Japanese government in articles from 2013 (FAZ5 and FAZ6) (Category E).

FAZ5 appeared on the business section with the title "Direktor Ono in heikler Mission" (Director Ono on a sensitive mission) [45]. The key words are: "Ono", "Tepco", and "Brennstäbe" (fuel rod). The article focuses on the director of the Fukushima Dai-ichi nuclear power plant "Ono" and his co-workers reporting about the dangers associated with the transportation of nuclear fuel rods from the reactor 4 in Fukushima, citing that "Kritiker warnen vor der größten atomaren Gefahr seit der Kubakrise" (critics warn of the greatest nuclear threat since the Cuba Crisis). In the text a quote from an interview with a Japanese professor of economic history was quoted, in which it was said that, "So hatten sie immer einen Sündenbock, dem sie den Schwarzen Peter zuschieben könnten, wenn etwas schiefging" (So [the government] had always a scapegoat, which they could blame).

FAZ6 was also published in November in the political column with the Title: "Im Schatten von Fukushima" (In the shadow of Fukushima) [46]. The key words of this article are: "Fukushima", "Regierung" (government) and "Tepco". The article reports that the Japanese government is not going to be able to achieve its goals to combat climate change because all 50 nuclear power plants are shut down. In the text it was described that "Nun ist Fukushima auch der Sündenbock dafür, dass Japan seine Klimaschutzziele nicht erreicht" (Fukushima is now also the scapegoat, for Japan not being able to reach its goals to combat climate change). The two uses of the term "Sündenbock", do not only showcase how the Japanese government blames the nuclear disaster in Fukushima for problems occurring in Japan, but also invokes the image that the Japanese government is shunning its responsibility.
The biblical term "Exodus" also appears twice in the German articles. Exodus, which describes a movement of departure, originates from the Old Testament (2.Mose 12:3142 ). It described the evacuation after the nuclear catastrophe in Fukushima. In articles from 2013 (SZ4) and 2016 (SZ5) the term "Exodus" was used in the form of "Massenexodus" which is a coinage from mass and exodus (Category F).

SZ4 was published on the third page of the Süddeutsche Zeitung with the title "Der Letzte seiner Art" (The last of his kind) [47]. The main key words of the article were: "Matsumura", "Naoto", "Tomioka". The article features the life of a resident in the contaminated area of Fukushima "Naoto Matsumura" in "Tomioka" who decided not to leave his home after the nuclear accident. The term was used in the sentence "Nach der Katastrophe im Kernkraftwerk Fukushima Dai-ichi im März 2011 kam es zu einem Massenexodus aus der Region." (After the catastrophe in the nuclear power plant Fukushima in March 2011, a mass exodus occurred from the region).

The same viewpoint and description reappears three years later. SZ5 was printed in 2016 on the Panorama section with the title "Grüße aus Fukushima" (Greetings from Fukushima) again interviewing Naoto Matsumura [48]. The key words were "Matsumura", "nicht" (not) and "Tomioka". "Massenexodus" appears in the sentence "Nur einer hat sich bockig dem Massenexodus widersetzt, hat den Behörden getrotzt und ist geblieben." (Only one has stubbornly opposed the mass exodus, had deified the authorities and stayed). In these two sentences including "Massenexodus", the biblical term illustrates the evacuation of the people after the Fukushima catastrophe. The term describes the fear of radiation felt by the fleeing residents who were living in the contaminated area of Fukushima. Also with the term "Mass" it shapes an image that the exodus was occurred on a grand scale. The readers could obtain an image referring to the story of Exodus where 600,000 Israelites, led by Moses, departed from Egypt (Ex. 12:31-42), experiencing emotions such as fear, anxiety and the pain of the evacuation. Considering that the Exodus in the bible is a positive story of people being freed from slavery and bonding together [49], the "Exodus" in the 3.11 article changes the scene in Japan into a negative context.

The biblical and liturgical terms, "Gläubige" (believers) and "Gebete" (prayers) were found, appearing conjointly with a photograph showing a group of Japanese people praying for the victims of the catastrophe (Category $\mathrm{G}$ ).

A short article with 93 words appeared in 2012 (FAZ7) reporting about the memorial of the victims of the tsunami and earthquake. FAZ7 appears on the front page of the newspaper one year after the catastrophe in 2012 with the title "Gebete für die Opfer" (Prayers for the victims) [50]. A picture with several praying people clad in white and black cloaks was placed on the center of the front page with the caption "Ein knappes Jahr nach der Katastrophe vom 11. März 2011 haben die Gläubigen im japanischen Natori für die Opfer von Erdbeben und Tsunami gebetet" (Barely one year after the catastrophe from March 11th 2011, believers in the Japanese Natori have prayed for the victims of the earthquake and tsunami) written beneath. The following text led to other featured articles relating to the catastrophe, as well as to the German energy policy. The word "Gläubige" 
in the caption refers to the believers of God (2.Kor. 6:15), And in this context, "Gebete" relates to the liturgical ritual of prayers to god (Ps. 4:4, Mt. 7:11). Praying to the victims of the catastrophe evokes a similar scene to the Christian custom of people praying and asking for the help of God or mourning the dead [51], [52]. This article does not only report an anniversary in Japan but also emphasizes the sadness and feelings of loss to the German readers. However below the article concentrating on the events in Japan, stands an article reporting about Germany's energy policy after the nuclear catastrophe in Fukushima with the title: "Arbeiten am Energieplan" (Working on the energy plan) [53]. From this layout, the possibility that the center article about Japan was not only featured to report about the anniversary of the catastrophe, but also to replay the story and the motives of Germany's political decision for the nuclear phase-out.

The term "Gott" (God) appeared in the Süddeutsche Zeitung in 2015 (SZ6) (Category H). SZ6 appeared on the political column. Its main key words were: "Kan", "Fukushima" and "Tokio" [54]. SZ6 with the title "Vor Schlimmeren bewart" (Saved from worse), it features former prime minister of Japan Naoto Kan, looking back at the catastrophe in Fukushima. "Gott" was used in an indirect quote from the Japanese ex-prime minister, when he was mentioning the consequence after the catastrophe in Japan, in the form of "Er glaubte, Gott habe Japan gerettet, sagt Kan" (Kan said that he thought God had saved Japan). The word "Gott" showcases his great relief that Japan had been saved from worse to the readers.

Other terms such as "Hiobsbotschaften" (in singular "Hiobsbotschaft") which defines bad news of impending crisis originating from the Book of Job in the Old Testament (Hiob. 1:13-19) were used to describe the constant new information of the problems from the Fukushima nuclear plant (Category I). In an article published in 2013 (SZ7) "Hiobsbotschaft" appears on the political column with the title: "Die Fiktion von der Kontrolle" (The fiction of control) [55]. The main key words of the article were: "Tepco", "Fukushima" and "Wasser" (water). The article reports about the continuing problem of contaminated water leaking from Fukushima nuclear power plant. The sub-title of the article SZ7 read:, "Falsche Messungen, neue Lecks, abstruse Bergungspläne: Aus Fukushima kommen immer neue Hiobsbotschaften" (False measuring, new leaks, absurd rescue plans: From Fukushima come always new Hiobsbotschaften). "Hiobsbotschaft" here not only represents the bad news from the nuclear reactor in the Fukushima power plant but also invokes feelings of fear of a crisis to the readers against the nuclear power plant.

"Hölle" (hell) (Mt. 5:22-29) referring to a place of damnation for sinners was selected to describe the disaster of the nuclear plant in Fukushima (Category J). In a report from 2012 (SZ8) the word appears on the political column with the title "Reaktorkühlung per Autobatterie" (Reactor cooling through car batteries) [56]. The key words were: "Tepco", "Fukushima" and "Yoshida". In the article a video recorded statement about the nuclear accident from Masao Yoshida, the former General Manager of the nuclear power plant is cited, "In seinem Video, das ein Kommunikationsberater aufgenommen hat, sagt er über das Reaktorunglück, es sei 'die Hölle' gewesen" (In his video, which a communication advisor recorded, he said about the nuclear accident that it was like hell). By using the term "hell" to describe the nuclear disaster from the former Manager, it does not only link images of hell to the actual disaster in Fukushima but also evokes associations of hell in the readers.

"Methusalem" which refers to the long living old man in the bible (1. Mose 5:25) appeared in the article of SZ2 mentioned above, in which the religious word "Apokalypse" was used in order to describe the Fukushima nuclear catastrophe (Category K). "Methusalem" appears in the following text as a metaphor of a cherry blossom tree in the contaminated area of Fukushima, "Oben von dem Tempel schorfig und bemoost, ein Methusalem von einem Kirschenbaum. Gerade hat er noch geblüht." (A Methusalem of a cheery blossom tree, above the Temple scabby and mossy. bloomed short while ago it was still in blossom). In this sentence the biblical symbol serves as a metaphor for the cherry tree in Fukushima allowing the readers to attribute the tree with old age.

The terms "Kloster" (cloister), "Mönch" (monk) and "Rosenkranz" (rosary) were used juxtaposed as a simile explaining the condition in the nuclear plant of Fukushima (Category L). An article from 2014 (FAZ8), which appeared in the Feuilleton (Art) column was a report from a journalist making a documentary film with the title "Fukushima jetzt" (Fukushima now) [57]. The main key words were: "Fukushima", "hier" and "Katastrophe" (catastrophe). FAZ8 recorded the journalists experience inside the Fukushima Dai-ichi power plant, three years after the catastrophe. In the article, the workers $\mathrm{n}$ the Fukushima nuclear plant, wearing white protection suits, are described in the following way: "In den langen Fluren kommen mir Arbeiter entgegen. Alle eingehüllt in weiße Schutzanzüge, wie Mönche eines unbekannten Ordens" (In the long hallways I encountered workers, walking towards me. All covered in white protection suits like monks of an unknown order). A similar situation was also mentioned in the sub-title of the photograph on the top of the page with the religious words "Kloster" (cloister) and "Mönch" (monk) showing people with cameras inside the nuclear plant wearing yellow helmets and white protections suits inside the facility. The sub-title reads: "Der Block 4 des Reaktors von Fukushima. In den Hallen herrscht eine eigenartige Stille. Man hat das Gefühl, in einem Kloster zu sein: Es gibt viele Rituale der Reinigung und Säuberung. Die Mönche tragen Kutten, wir tragen unsere Schutzkleidung" (The Block 4 of the reactor in Fukushima. In its halls reigns a unique silence. One feels like inside a cloister. There are many rituals of purification and cleansing. The monks wear cowls, we wear our protection suits).

Linking the image of "Monks" the report continued to describe the Geiger counters as a rosary: "Die Reinigungsprozeduren, dieses Übersteigen von Schwellen, das Ausziehen von Schuhen ... Statt eines Rosenkranzes händigt man uns Dosimeter aus" (The process of cleaning, climbing over sills and taking off shoes ... instead of a rosary we are handed dosimeters). By linking the atmosphere in the nuclear plant to familiar images, it does not only make it easier for the reader to understand the experience of the reporter but also conveys the quiet and ritual atmosphere of the nuclear plant. 
"Wiederauferstehen" (resurrection) (Lk. 24:34, 1.Thess. 4:14) and "Wiedergeburt" (revival) (Tit. 3:5, Mt. 19:28) were used when reporting about the reconstruction of the disaster-hit area of the tsunami catastrophe (Category M).

"Wiederauferstehen" appears at the end of FAZ1 in a quote from the mayor of the destroyed city of Kesenuma in Japan saying, "Die Stadt sitze in der Falle, denn 'überleben und wiederauferstehen können wir hier nur mit dem Meer' ", (The town is trapped, because we can only survive and rise again together with the ocean).

The term "Wiedergeburt" was used in an article printed in 2016. The term was used as a title for the article FAZ9 "Schwierige Wiedergeburt nach dem Tsunami" (Difficult revival after the tsunami) [58]. The main key words were: "Ishinomaki", "Tsunami" and "Menschen" (people). The article explains the difficulties of the reconstruction and the situation of the still-struggling victims in the tsunamistricken cities in the Tohoku area of Japan. "Wiedergeburt" was also used in the sentence, "In Ishinomaki, das von dem Tsunami so hart wie kaum eine andere Stadt getroffen wurde, lässt sich die Wiedergeburt der Stadt erheblich langsamer an" (In Ishinomaki which was affected by the tsunami as hard as almost no other city, the revival is considerably slower). Both expressions refer to the re-birth of god in order to illustrate the revival of the disaster-hit area.

The term "Wiederauferstehen" or "Wiedergeburt", which means resurrect, refers to the resurrection of Jesus, which describes the victims' hope and expectation of redemption and also affects the minds of the readers. There is also a question attached to the context of the article, whether the city of Kesenuma and its citizens can recover in the future.

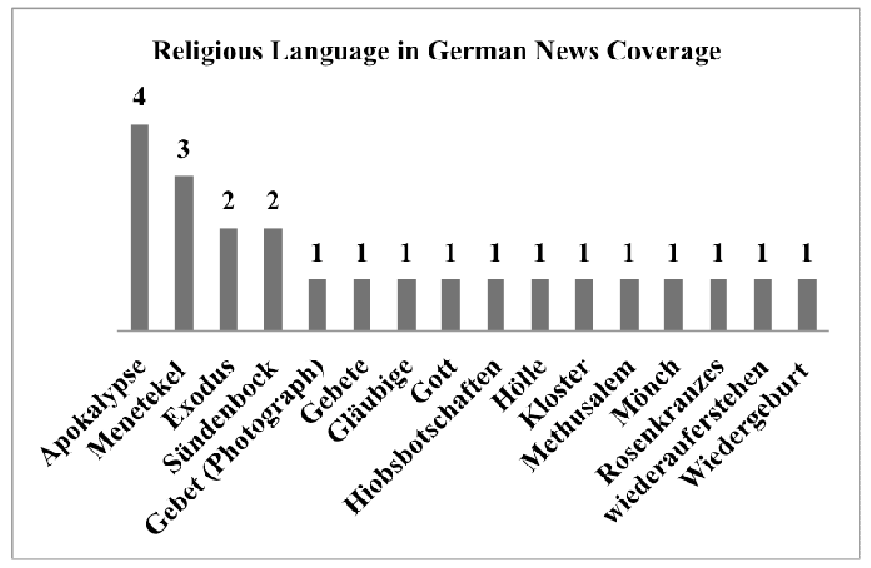

Fig. 4 Frequency of the religious language appearing in German news coverage

\section{B. Text Analysis of American News Coverage}

Fig. 5 shows the results of the analysis of the American news coverage. Through the text analysis the theological word "limbo" was the most used religious term in the American newspapers throughout year 2013 to 2015. "Limbo" which describes a period of a non-moving situation or condition originates from a theological term which represents the border between heaven and hell where the souls are deprived of the joy of eternal existence with God in heaven [59], was used when describing about the conditions of the nuclear plant and refugees of the nuclear catastrophe in
Japan. This research paper presents a deeper analysis of the functions of the religious words used in the American articles. By analyzing the terms in the American articles, the functions can be categorized into categories $\mathrm{A}$ to $\mathrm{H}$.

"Limbo" was the most used religious word in the American articles used in 2013 (WP1, NYT1, NYT2), in 2014 (NYT3) and in 2015 (NYT4). "Limbo" appeared as a term to describe the situation of the non-working nuclear power reactors in Japan, which can make the readers doubt the restart of nuclear power plants in Japan. This can be seen in WP1 and NYT1 (Category A).

WP1 was posted on the international column. The main key words are: "nuclear", "power" and "Oma". WP1 was printed on March 112013 titled "Two years after crisis in Japan, a bet on nuclear power" reporting that Japan has decided on a nuclear phase out until 2030, while a new nuclear power plant is planned to be built in Oma [60]. In this article the situation of the nuclear power plant was described as "Two reactors in western Japan restarted in July, but others remain in limbo, requiring major reinforcement against earthquakes, tsunamis and other disasters". "Limbo" which has a connotation of the longing of the soul that awaits the redemption of God was used as a term to describe the contemporary state of the non-active nuclear power plant in Japan, which can not only refer to the image of the reactors but also create an expectation to the possibility of the restart of the power plants. NYT1 appeared on the international column on May 16th 2013 [61]. A photograph of the nuclear plant was placed on the top of the article. The main key words are: "nuclear", "reactor" and "Tsuruga". Titled "Japanese Reactor Is Said to Stand on a Fault Line", the article describes the situation of the nuclear plant Monju in Tsuruga city, as "But the authority does not have legal power to order a permanent shutdown, a situation that could leave thereafter in limbo", which refers to the situation of the nuclear plant describing the uncertainty whether it will restart or not.

"Limbo" would be also used to describe the situation of the refugees suffering from the aftermath of the Fukushima nuclear disaster (Category B).

This can be seen on article NYT2 and NYT3 which are articles focusing on the victims who were suffering from the after-effects of the nuclear accident in Fukushima. NYT2 was located on the front page on October 2nd 2013 [62]. The main key words are: "Namie", "government" and "town". The article is titled "Japan's Nuclear Disaster Refugees, Still Stuck in Limbo". NYT2 reported that the residents are giving up returning back to the disaster zone in Fukushima as the government continues its cleanup of the radiation in Namie city. "Limbo" was used in the title and also in the main text describing the situation of the refugees in Fukushima as "which some have moved on, reluctantly, but tens of thousands remain in a legal and emotional limbo while the government holds out hope, that they can one day return". Here by using the term "limbo", the connotation of the suffering of the soul expecting the redemption of God interlocks with the text, illustrating the fear and feelings of loss of the refugees, referring also to the question of whether their lives and the city will be able to revive or not.

NYT3 appeared on the international column on April 28th 2014 [63]. The main key words are: "radiation", 
"compensation" and "government". The article NYT3 titled "Forced to Flee Radiation, Fearful Japanese Villagers Are Reluctant to Return", wrote that the refugees in the city Miyakoji near the Fukushima Dai-ichi power plant are doubting the government and the media reports of the decontamination being completed. In the article, describing the situation of the evacuees as "As a result, many evacuees have been forced to live in a state of limbo since the accident, unable to leave barracks-like temporary housing, or end their dependency on Tepco for monthly stipend to live in apartments outside the village". By using the term "state of limbo" it can describe the painful emotions of the refugees, and also trigger the expectation of redemption of the evacuees in Fukushima.

This term also described the difficulties of the people working on a renewable energy project (Category C). NYT4 was printed on the page 1 business column on March 4th 2015 titled "Shot-Circuiting a Solar Boom in Japan" [64]. The main key words are: "solar", "power" and "energy". "Limbo" was used by explaining a solar energy project in Kagoshima as following: "An additional 8.4 gigawatts' worth of projects, including Mr. Akagi's on Ukujima, have received government approval but are in limbo after Kyushu Electric's edict". The symbol illustrates not only the non-progressing state of the project but also the difficulties of the actors in the energy project.

The word "exodus", symbolizing the book of Exodus in the Old Testament which was also seen once in the German article followed as the most used religious language in the American articles in year 2015 and 2016 as a metaphor of mass movement such as evacuation of the refugees of the nuclear disaster. "Exodus" was used in articles which appeared in 2015 (NYT5), 2016 (NYT6, NYT7). The word was used as a term for people, evacuating from their hometown, which also illustrates the emotions of sorrow and fear throughout the text (Category D). This could be seen in NYT5, which appeared on the international column on March 13th 2015 [65]. The main key words are: "town", "Otsuchi" and "tsunami". The article's title reads "A Struggle to Recover as Vast as the Ocean". It focused on the disasteraffected city of Otsuchi, that does not show any signs of recovery from the damages of the tsunami, some people having decided to move out of the city, although many still remain in makeshift housing. The story describes the decreasing population using the word "exodus" in the sentence: "The town hall estimates that Otsuchi has lost at least a quarter of its population to the disaster and the exodus that followed". The readers could obtain an image referring to the story of Exodus where 600,000 Israelites, led by Moses, departed from Egypt (Ex. 12:31-42), experiencing emotion such as fear, anxiety and the pain of the evacuation. As seen in the German article, the "exodus" in the article changes this original definition into a negative context.

"Exodus" was also used in other articles to describe the withdrawal of companies from Japan, in order to leave behind their financial problems, which can also implicate to the readers, that Japan's economy is also in a hard situation (Category E). This can be seen in NYT6 and NYT7.

NYT6 appears on the international column on March 10th 2016 [66]. The main key words are: "power", "nuclear" and "Takahama". Titled "Court Orders One of Japan's Two
Operating Nuclear Plants to Shut Down", this article reports that a lawsuit has been filed by the Japanese residents near the operating nuclear plant in Takahama. In the article, not only the activities of the Japanese residents, but also the perspective of the Japanese government was described as: nuclear power as critical to supporting economic growth and slowing an exodus of Japanese manufacturing to lower-cost countries". The term "exodus" was used as a metaphor to represent the movement of Japanese companies to other countries. The use of "exodus" refers not only to the movement of the companies but also implicates the economic hardships in Japan.

NYT7 appeared on the business column on April 14th 2015 [67]. The main key words are: "nuclear", "power" and "judge". Article NYT7 is titled "Nuclear Reactors in Japan Remain Closed by Judge's Order". The article, relates to NYT6, reporting that the local judge has forbidden the restart of the two nuclear power plants in Takahama. The article also reported that "Prime Minister Shinzo Abe's government sees a revival of nuclear power as critical to supporting economic growth and slowing an exodus of Japanese manufacturing to lower-cost countries", which invokes the same images as mentioned in NYT6 above.

Other obvious religious terms such as "baptized", "congregation", "church", "God", "faith", "pastor" and "prayed" have been used in the same article printed in 2013 (NYT8) on the international section. NYT8 titled "Uprooted by Tsunami Church's Flock Regroups" reported the struggling journey of the members of a church near the Fukushima Dai-ichi nuclear power plant "fleeing from radiation" two years after the catastrophe [68]. NYT8 reports how the Japanese Christian evacuees in Fukushima overcame the crisis together after the nuclear disaster, which was seen as a challenge from god (Category F). The main key words were: "church", "plant" and "Fukushima". The article involves several religious terms in the text focusing on the activities of the parishioners. The term "God" appeared in a quote from a Japanese pastor in the article citing that "There were times when we felt like we lost everything that we hold dear, and we asked: 'God why?' ". Reporting how the parishioners struggled through the catastrophe the article follows "But the opening of its new chapel this month, at least, ends a two-year-journey that members say tested the faith of even the most faithful."

This story is relevant to the story in the bible where god tests the faith of the believers (1.Pet. 1:6-7, Jas. 1:2-4). Featuring the victims of the Christian refugees of the nuclear catastrophe this article does not only convey the suffering or pain of the victims of the nuclear catastrophe but moreover the American reader could reciprocate their feelings with the victims of the catastrophe in Japan.

The term "Hail Mary" was seen in an article printed in 2016 in the New York Times (NYT9). NYT9 titled "An Invisible Dike", the main key words of the article were: "wall", "water" and "ice" [69]. NYT9 reported about the built underground ice wall at the Fukushima Dai-ichi nuclear station. The "Hail Mary" which appeared in an interview quote from a Japan-based researcher citing that the ice wall plan is a "Hail Mary play" appeared in the quote " 'It's a Hail Mary play,' said Azby Brown, a Japan-based researcher for Safecast, an independent radiation-monitoring group. 'Tepco 
underestimated the groundwater problem in the beginning, and now Japan is trying to catch up with a massive technical fix that is very expensive.' ". The term "Hail Mary play" in this context associates with the term used in American football "Hail Mary pass", which means an "unlikely gamewinning toss" at the end of the game, in this context meaning the slight chance of success of the ice wall project [70]. However this term originates from "Hail Mary" representing the prayer to the Virgin Mary in the bible (Lk. 1:28). The biblical term invokes questions in the readers whether the ice wall would be a success or not as well as whether the nuclear plant as well as the people in Fukushima could be saved (Category G).

Also as seen in the German newspaper article the gesture of "prayers" in Japan for the victims of the catastrophe was seen in the form of a photograph, one year after the catastrophe (Category $\mathrm{H}$ ). This was seen in an article from the New York Times in 2012 (NYT10). NYT10 was titled "An Anniversary of 'Heartbreaking Grief' in Japan" and the main key words were: "Namie", "nuclear" and "radiation" [71]. The article concentrated on the memorial of the victims of the catastrophe in the city of "Namie" in Fukushima prefecture reporting about the life of the victims' families. A photograph of a memorial was placed on top of the article with the following sub-title: "People visited a memorial at an elementary school near Ishinomaki, Japan, where 74 children died in the tsunami that occurred a year ago on Sunday." The photograph focused on a praying child.

Together with the article, the picture also relates to the same custom of the readers, when people pray for and mourn the dead. It does not only illustrate the sorrow of the people in Japan but also affects the feelings of the reader, sharing feelings of sadness and pain.

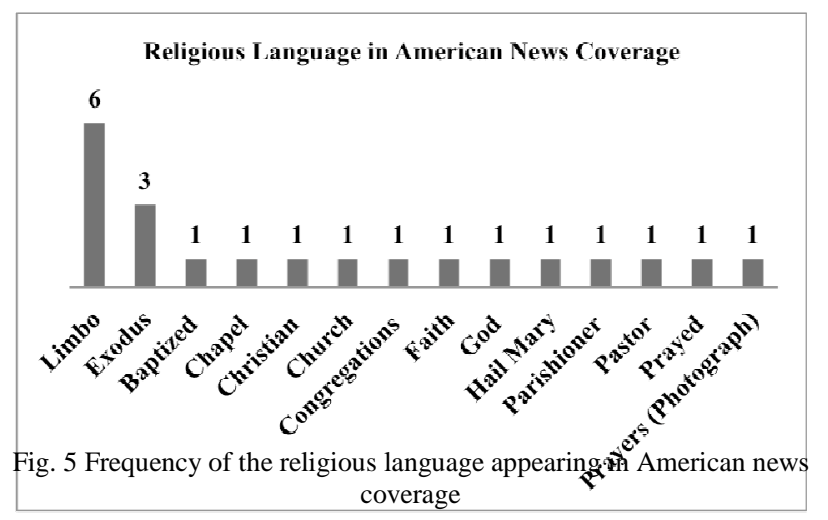

\section{CONCLUSION}

This research paper analyzed and determined how religious words function in the news coverage related to the theme of the earthquake, tsunami and nuclear catastrophe in Japan 2011 by focusing and comparing Japanese, German and American news articles which were printed after 2012 postulating that the religious words, such as metaphors and symbols have the function for internal representation in the news report as well as to affect the reception of the readers inner mind and feelings.
Religious words, despite the decreasing number of articles related to the events referring to o the 3.11 catastrophe in Japan were continuously used both at the national newspaper level in Germany and America. Also no statistical difference was found in the amount of the used religious words in both languages.

Through the analysis viewing the whole result comprehensively, it can be concluded that religious words serve as a tool to express specific situations and to convey emotion to the readers.

In this research, it is taken into account that the analyzed religious language in the news coverage would not be directly connected to religious thoughts or meaning but moreover referred to other synonyms of the religious terms in the modern usage. Also, it is acknowledged that religious terms in the media have a complex connotation, which makes it difficult to define what a religious term is. This depends on the recipients, as well as the sender of the text. Because of this, the religious language examined in this research paper is limited to expressions whereof their biblical or liturgical origins are apparent.

Taken these limitations into account, religious words in the 3.11 coverage serve as metaphors, symbols or representations, which have a connotation to the bible, theology or liturgy. Religious terms make it possible to illustrate not just a disaster but rather the massive destruction of the city by the tsunami as well as by the nuclear disaster in Fukushima comparing the devastating image referring to the story of the apocalypse in the Revelation.

Moreover the goal is to illustrate the fear, difficulties and hope of the local people. Religious language goes beyond the criteria of secular news reports, provoking emotions in the reader and making it easier for them to understand the situation of Japanese social issues or the state of nuclear reactors as well as the refugees of the tsunami and nuclear disaster catastrophe. It also invokes ambivalent questions whether the destroyed city, as well as the society in Japan could revive or not.

Looking at the similarities of the used religious terms used in the German and American articles, the term "Exodus" was used in the same description for evacuation of the Japanese people after the catastrophe. Also, the term "God" was chosen to be used in the report in a quote from the Japanese people when they mentioned the term, asking for an answer why the refugees must face such severe situations after the catastrophe in the American article or mentioning that Japan was saved from God during the catastrophe in the German newspaper. The term "Prayers" along with the photographs of the praying people were to be seen in both languages. This describes that the German and American reports share similar perspectives and values when delivering the 3.11 catastrophe related news from Japan.

However when looking at the difference of the use of religious language between Germany and America it could depend on the countries differing stances considering nuclear energy.

Comparing the results from the text analysis in Germany and the United States, Germans use the word "Apokalypse", "Menetekel" and "Hiobsbotschaft", while Americans will use the term "Limbo" in order to describe the situation of the nuclear issues in Fukushima. The reason for this difference 
lies within the society. Germany has been against nuclear power, ever since the first commercial reactor has been running, especially since Chernobyl and Fukushima. The nuclear accident in Fukushima has changed Germany's energy policy, hastening the "Energiewende" and the nuclear phase-out until 2022 [72]. The majority of the public opinion still supports the policy of the nuclear phase-out [73]. On the other hand America produces $19 \%$ of their energy by using 100 nuclear reactors in their nation [74], which makes nuclear energy one of the most essential methods of energy production in the United States. In Contrast to Germany, a strong opposition to nuclear energy cannot be seen [75]. Especially in the German articles the religious words can invoke the emotion and change the viewpoint of their readers, from the issues of Japan to the issues in their own country. From this point, religious expressions in the articles related to the catastrophe have a similar function to the media control, as shown in previous research.

Based on this result, further text analysis must be continuously conducted for this research and not only national but also regional news papers in Germany and America must be investigated in order to see the difference of the tendency and/or frequency in the use of such religious terms utilized in the same language but different area of region. In addition the position of the media and the political stance of the region must be considered in order to analyze further of how the religious terms could function in a specific region. This further investigation also links to prove the validity of the function of the religious language used in the media coverage.

Moreover it is also considered important to research and compare the terms in another context not just only terms linked to the context of the 3.11 catastrophe in Japan in order to generalize the results of this analysis. Furthermore in order to see variances among the function of the religious language, not just only German and English but also other languages should be analyzed and compared. Also surveys or interviews must be conducted with readers and journalists in order to find out and compare their perspectives on how they receive and send each article, which are essential parts of this research in order to clarify the function of the religious language in the media news coverage.

\section{REFERENCES}

[1] S. Ogiwara, Terebi Nyūsu no Sekaizou, Gaikoku Kanren Houdou ga Kouchiku suru Riaritī̄, Tokyo, Japan: Keiso Shobou, 2006.

[2] E. Gottwald, Mögliche Felder der Zusammenarbeit zwischen Medienpädagogik und Religionspädagogik aus der Sicht einer Didaktik der religiösen Kommunikation, 1st ed., M.L.Pirner, T. Breuer, Ed. München, Germany : kopaed, pp. 36-42, 2004.

[3] Q. J. Schultze, Christianity and the Mass Media in America: Toward a Democratic Accommodation, Michigan, USA: Michigan State University Press, 2005.

[4] M. R. Ishiguro, Seisho de Yomu America, Kyoto, Japan: PHP Kenkyujyo, 2006

[5] A. Moore, Iconography of Religion, An Introduction. Minnesota, USA: Fortress Press, 1992.

[6] Asahi Shimbun, Asahi Shimbun Shupann Ed., Houdou Shashin Zenkiroku Shuu 2011.3.11-4.11 Higashi Nihon Daishinsai (Complete compilation of press photos about the Great East Japan Earthquake from 2011.3.11-4.11), Tokyo, Japan: Asahi Shimbun Shupann, 2011.

[7] Yomiuri Shimbun, Higashi Nihon Daishinsai Yomiuri Shimbun Houdou Shasin Shuu (Compilation of Yomiuri Shimbun press photos on the Great East Japan Earthquake), Toyko, Japan: Yomiuri Shimbun, 2011
[8] Kahoku Shimpo, Higashi Nihon Daishinsai Zen Kiroku: Hisaichi kara no Houkoku (Complete compilation of the Great East Japan Earthquake: A report from the disaster area), Sendai, Japan: Kahoku Shimpo, 2011.

[9] Kyodo News, Higashi Nihon Daishinsai: Tokubetsu Houdou Shashin Shuu (The Great East Japan Earthquake special press photo compilation), Tokyo, Japan: Kyodo News, 2011.

[10] T. Uesugi, Shinbun Terebi ha Naze Heiki de Uso wo tsuku noka, Tokyo, Japan: Gentosha, 2012.

[11] M. Fackler, Hontouno Koto wo Tsutaenai Nihon no Shimbun, Toyko, Japan: Futaba Shinsho, 2012.

[12] Yokouchi, Nobuaki et al., "News Reports on East Japan Great Earthquake in Four Contries: Comparative Analysis with Articles During One Month After the Disaster," Sociotechnica, vol. 9, pp.129, Oct. 2012

[13] Sakai, Makoto, "Analysis of comparative English media reports about the aftermath of the Fukushima Daiichi nuclear power plant disaster ( $<$ Special feature $>$ The Future of the Journalism and Media)," Information Science and Technnology Association, vol. 65, pp.27-33, May. 2015.

[14] J. Wolling, D. Arlt, Ed. Fukushima und die Folgen. Meidenberichterstattung, Öffentliche Meinung, Politische Konsequenzen, Ilmenau, Germany: Univeristätsverlag Ilmenau, 2014.

[15] M. Koch, H. Meyer, T. Nishiyama, R. Zöllner, Meida-Contents und Katastrophen. Beiträge zur medialen Verarbetung der Großen Ostjapanischen Erdbebenkatastrophe. München, Germany: ludicium Verlag GmbH, 2016.

[16] G. Ward, M. Hoelzl, Ed., The New Visibility of Religion, Studies in Religion and Cultural Hermeneutics, ser. Continuum Resources in Religioun and Political Culture, London, UK: Bloomsbury Academic, 2008, vol.1.

[17] V. Wieser, L. Schlöndorff, Abendländische Apokalyptik. Kompendium zur Genealogie der Neuzeit, Kompendium zur Genealogie der Neuzeit, Berlin, Germany: Akademie Verlag, 2013.

[18] S. Orgad, Representation and the Global Imagination, New Jersey, USA: John Wiley \& Sons, 2014

[19] M. Miyata, Nachi Doitsugo to Gengo, Hitorā Enzetsu kara Minshū no Akumu made, Tokyo, Japan: Iwanami Shinsho, 2002.

[20] N. Chomsky, The Spectacular Achievements of Propaganda, 1st ed., New York, USA: Seven Stories Press, 2002.

[21] J. Charteris-Black, Politicians and Rhetoric: The Persuasive Power of Metaphor, Palgrave Macmillan, 2004.

[22] R. Wodak, M. Mayer, Critical Discourse Analysis: History, Agenda, Theory, and Methodology, Basingstoke, UK: SAGE Publications, 2009.

[23] T. van Dijk, Discourse and Communication, Approaches to the Analysis of Mass Media Discourse and Communication. Oxon, UK: Routledge, 1989.

[24] S. Tischner, M. Meyer, R. Wodak, E. Vetter, Methods of Text and Discourse Analysis : In search of Meaning, New York, USA: SAGE Publications, pp.148-154, 2000.

[25] T. van Dijk, 18 Critical Discourse Analysis. In: Schriffrin”, The Handbook of Discourse Analysis, Oxford,UK: Blackwell, pp. 352378, 2001.

[26] S. Lynch, P. Limor, Analyzing Newspaper Content A How-To Guide: Including National Comparison Data for U.S. Data Newspapers, Illinois, USA: Readership Institute, 2002.

[27] D. Cruse, F. Hundsnurscher, M. Job, P. R. Lutzeier. Ein internationals Handbuch zur Natur und Struktur von Wörtern und Wörtschätzen, vol. 1 Sonderdruck, Berlin, Germany: Walter de Gryter, 2002.

[28] (2016) Luther 1912. [Online]. Available: http://www.bibel-online.net

[29] (2016) King James Bible Standard. [Online]. Available: http://www.kingjamesbibleonline.org

[30] (2016) Japan Bible Society. [Online]. Available: http://www.bible.or.jp

[31] (2016) Der Bundesverband Deutscher Zeitungsverleger e.V. [Online]. Available: http://www.bdzv.de

[32] T. Groseclose, J. Milyo, "A Measure of Media Bias," The Quarterly Journal of Economics, vol. 120, pp. 1197-1237, Nov. 2005

[33] The Huffington Post (2011), "The 25 Biggest Newspapers In America," [Online]. Available: http://www.huffingtonpost.com/2011/05/03/ newspaper-circulationtop-25_n_856910.html

[34] M. Gaulene (2010), "Yomiuri Shimbun: The giant of the Japanese press," INA global. [Online]. Available: 
http://www.inaglobal.fr/en/presse/article/yomiuri- shimbun-giantjapanese-press

[35] C. Wetzel, Das Große Lexikon der Symbole. Darmstadt, Germany: Primus Verlag, 2011.

[36] W. Gerlach, Das neue Lexikon des Aberglaubens, Frankfurt am Main, Germany: Eichborn, 1992.

[37] C. Germis, "Neuanfang mit Hindernissen", Frankfurter Allgemeine Zeitung, p.14, Mar. 9th 2013.

[38] Süddeutsche Zeitung, "Fukushima - ein Jahr danach", Süddeutsche Zeitung, p.2, Mar.10/11th 2012.

[39] S. Klein, "Stunde eins", Süddeutsche Zeitung, p.3, May 20th 2016.

[40] K.M. Beisel, "Schönheit der Apokalypse", Süddeutsche Zeitung, p.12, Mar. 10th 2016.

[41] U. Meyer, "Fukushima bleibt nur Totenwache", Frankfurter Allgemeine Zeitung, p.35, Sept. 6th 2013.

[42] P. Welter, "Mit Kernkraft und Kohle", Frankfurter Allgemeine Zeitung, p.15, May 20th 2015.

[43] P. Welter, "Japans Lehren nach dem Tsunami", Frankfurter Allgemeine Zeitung, p.17, Mar. 9th 2016.

[44] S. Scheidlinger, "Presidential Address: On Scapegoating in Group Psychotherapy", International Journal of Group Psychotherapy, vol. 32, pp.131-143, Oct. 1982.

[45] C. Germis, "Direktor Ono in heikler Mission", Frankfurter Allgemeine Zeitung, p.5, Nov. 9th 2013.

[46] C. Germis, "Im Schatten von Fukushima", Frankfurter Allgemeine Zeitung, p.13, Nov. 16th 2013.

[47] S. Klein, "Der Letzte seiner Art", Süddeutsche Zeitung, p.3, Aug. 5th 2013.

[48] S. Kleiin, "Grüße aus Fukushima”, Süddeutsche Zeitung, p.8, June 13th 2016.

[49] C. Meyers, Exodus, Cambridge. UK. Cambridge University Press, 2005.

[50] Frankfurter Allgemeine Zeitung, "Gebete für die Opfer", p.1, Mar. 9th 2012.

[51] Evangelischer Oberkirchenrat, Gottesdienstbuch für die Evangelische Landeskirche in Württemberg: Die Bestattung. Stuttgart, Germany: Evangelisches Medienhaus GmbH, 2000.

[52] Katechismus der Katholischen Kirche 1997 (2007) Liberia Editrice Vaticana. [Online]

Available: http://www.vatican.va/archive/DEU0035/_INDEX.HTM

[53] A. Mihm, "Arbeiten am Energieplan". Frankfurter Allgemeine Zeitung, p.1, Mar. 9th 2012.

[54] C. Neidhart, "Vor Schlimmeren bewart", Süddeutsche Zeitung, p.9, Sept. 17th 2015.

[55] C. Neidhart,"Die Fiktion von der Kontrolle", Süddeutsche Zeitung, p.7, Sept. 2nd 2013
[56] C. Neidhart, "Reaktorkühlung per Autobatterie", Süddeutsche Zeitung, p.7, Aug. 14/15th 2012.

[57] R. Yogeschwar, "Fukushima jetzt", Frankfurter Allgemeine Zeitung. p.33, Nov. 2nd 2014.

[58] P. Welter, "Schwierige Wiedergeburt nach dem Tsunami", Frankfurter Allgemeine Zeitung, p.18, Mar. 11th 2016.

[59] (2016) Encyclopaedea Britannica 2016. [Online] Available: http:// www.britannica.com

[60] C. Haran, "Two years after crisis in Japan, a bet on nuclear power", Washington Post, p.A9, Mar. 11th 2013.

[61] H. Tabuchi, "Japanese Reactor Is Said to Stand on a Fault Line", New York Times, p.A8, May 16th 2013.

[62] M. Fackler, "Japan's Nuclear Disaster Refugees, Still Stuck in Limbo", New York Times, p.1, A8, Oct. 2nd 2013.

[63] M. Fackler, "Forced to Flee Radiation, Fearful Japanese Villagers Are Reluctant to Return”, New York Times, p.A4, Apr.28th 2014.

[64] J. Soble, "Short-Circuiting a Solar Boom in Japan", New York Times, p.B1, Mar. 4th 2015.

[65] M. Fackler, "A Struggle to Recover as Vast as the Ocean", New York Times, p. A4, Mar. 13th 2015.

[66] J. Soble, "Court Orders One of Japan's Two Operating Nuclear Plants to Shut Down", New York Times, p.A8, Mar. 10th 2016

[67] J. Soble, "Nuclear Reactors in Japan Remain Closed by Judge's Order", New York Times, p.B1, Apr. 14th 2015

[68] H. Tabuchi, "Uprooted by Tsunami Church's Flock Regroups", New York Times, p. A7, Mar. 11th 2013.

[69] M. Fackler, "An Invisible Dike", New York Times, p.D1, Aug. 30th 2016.

[70] J. Walters (2016) "How 'Hail Mary' Became Inextricably Linked to American Football". Newsweek. [Online]. Available: http://europe.newsweek.com/theres-something-about-hail-mary$510723 ? \mathrm{rm}=\mathrm{eu}$

[71] H. Tabuchi, "An Anniversary of 'Heartbreaking Grief' in Japan", New York Times, p.A4, Mar. 12th 2012.

[72] (2016) Die Bundesregierung. [Online]. Available: https://www.bundesregierung.de/Webs/Breg/DE/Themen/Energiewe nde/node.html

[73] (2016) U.S. NRC. [Online]. Avaiable: http://www.nrc.gov

[74] Bild (2015), "Deutsche wollen keinen Atomstrom mehr". [Online] Available: http://www.bild.de/politik/inland/atomausstieg/4-jahrenach-fukushima-grosse-mehrheit-fuer-energiewende40148648.bild.html

[75] Gallup (2016), "Energy". [Online]. Available: http://www.gallup.com/poll/2167/energy.aspx 